\title{
Bela, maternal e feminina. Imagens da mulher na Revista Educação Physica, de Silvana Goellner, Ijuí: Unijuí, 2003 (Coleção Educação Física)
}

Maria Simone Vione Schwengber

\begin{abstract}
Resumo: O livro Bela, maternal e feminina. Imagens da mulher na Revista Educação Physica é fruto da tese de doutorado defendida por Silvana Goellner junto ao Programa de Educação-UNICAMP-Campinas. Goellner, de forma inteligente e original, explora à exaustão Revista Educação Physica que circulou no Brasil entre os anos de 1932 e 1945. A autora focaliza, inicialmente, o tempo em que a Revista Educação Physica foi produzida. Em seguida, pergunta: qual o lugar da Educação Física nesse tempo? Desse modo, a sua análise é fortemente situada e centrada na história e no corpo feminino.Silvana Goellner, com sensibilidade, vê nas páginas da publicação três eixos que ecoam quase como um mandamento na "feitura" do corpo feminino: seja bela, seja maternal e seja feminina. Palavras-chave: Corpo, Gênero, Educação Física.
\end{abstract}

O livro Bela, maternal e feminina. Imagens da mulher na Revista Educação Physica é fruto da tese de doutorado defendida por Silvana Goellner junto ao Programa de Educação-UNICAMP-Campinas. Pelo título (numa leitura meteórica), poderíamos pensar que trata de "imagens [corpos] de mulheres". Porém, o livro não trata apenas do corpo feminino, mas da Educação Física no Brasil, o solo fecundo sobre o qual a autora vai construir sua rigorosa análise.

A escolha da Revista Educação Physica como fonte de investigação é um marco na produção de pesquisa na Educação Física brasileira. Goellner, de forma inteligente e original, explora à

\footnotetext{
1 Doutoranda em Educação na Universidade Federal do Rio Grande do Sul (UFRGS), vinculada à linha de pesquisa Educação e Relações de Gênero, orientanda da Doutora Dagmar Meyer. É professora do Departamento de Pedagogia - Curso de Educação Física da Universidade Regional do Noroeste do Estado do Rio Grande do Sul (UNIJUí).
}

Movimento Porto Alegre, v.9, n. 3, p.165-173, set./dez. de 2003 
exaustão a revista que circulou no Brasil entre os anos de 1932 e 1945. A autora traz à tona, pouco a pouco, a multiplicidade de discursos e saberes instituídos pela Revista Educação Physica no processo de educar os corpos, codificá-los, classificá-los e, supostamente, explicá-los.

Silvana Goellner retira desses periódicos duas leituras: a das narrativas escritas e a das imagens. E é a partir da leitura das imagens que a autora oferece uma valiosa contribuição para a área da Educação Física: ela lê as imagens de uma forma sofisticada e especificamente histórica, distanciando-se, em muito, dos trabalhos que utilizam de modo corriqueiro as imagens apenas de maneira ilustrativa.

A autora focaliza, inicialmente, o tempo em que a Revista Educação Physica foi produzida. Em seguida, pergunta: qual o lugar da Educação Física nesse tempo? Desse modo, vê-se que a análise é fortemente situada e centrada na história. Goellner aponta que o tempo de produção da Revista Educação Physica foi um tempo de significativas mudanças econômicas, sociais e culturais na sociedade brasileira e, por conseqüência, também na Educação Física, destacando os diferentes acontecimentos que marcaram essa área no Brasil. Foi um período fértil em que a Educação Física se identificava como prática capaz de colaborar na construção de um projeto nacional de engrandecimento da Pátria e de fortalecimento da população. A autora destaca o temor à degenerescência da raça e, ao mesmo tempo, o quanto a Educação Física vê-se embalada pela batuta "é preciso ter força, é preciso ter graça, é preciso ter raça" (canção de Milton Nascimento).

A autora, com muita sensibilidade, vai dando as pistas para o leitor compreender as razões pelas quais as práticas corporais foram amplamente incentivadas no contexto brasileiro dos anos 30. Afinal, a Educação Física, nesse momento, era uma prática social, dita da vida moderna, que comportava em seu bojo a promessa de poder contribuir para o regulamento dos corpos, torná-los mais eficientes, produtivos, civilizados, limpos. Era uma prática capaz de instituir hábitos moralizados da "vida ativa" em contraposição à indolência de corpos preguiçosos, fracos, incivilizados da vida sedentária.

Para Goellner, a Revista Educação Physica revela o quanto a Educação Física estava mergulhada nesse universo de euforia cívica de progresso social. Para a autora, a Educação Física acei- 
ta e atrai para si a tarefa de divulgar e de orientar pedagógica e cientificamente o robustecimento da população. A autora destaca o compromisso que a revista tem "com a divulgação da idéia de que a Educação Física e os esportes são fundamentais na formação da juventude e na preparação de mulheres e de homens para o enfrentamento dos obstáculos inerentes à vida cotidiana, urbana e moderna" (p.19). Vê-se a Educação Física como promotora de saúde, responsável pelo fortalecimento do povo e pela eugenia da raça.

Qual é a singularidade do livro Bela, maternal e feminina? O/ a leitor/a logo perceberá que a singularidade está na sua trama, na forma pela qual a autora, convivendo com o debate instaurado pela sua área de conhecimento, produz uma abordagem inconfundível no arranjo que dá aos elementos históricos. Ela afirma que procura, nos fragmentos do passado, os vínculos, as persistências e as possibilidades com o presente e o futuro. O passado é considerado "não no seu desenrolar contínuo e cronológico", mas "na descontinuidade dos enlaces" com que organizou seus dados. Afirma, ainda, que, se é chamada por apelos do passado, então "apela" a esse passado para melhor compreender o presente.

Para Goellner, a Revista Educação Physica é identificada como uma das primeiras publicações a demarcar uma especificidade para a Educação Física. A publicação apresenta-se como um veículo de divulgação de idéias "modernas" sobre os diferentes saberes relacionados à educação do corpo. Nesse contexto, a sociedade brasileira crê na educação como fator fundamental de regeneração e renovação nacional.

A autora, na condição de pesquisadora, quase que sussurra, pouco a pouco, nos ouvidos dos leitores, uma espécie de opção política (ela tem um estômago capaz de regurgitar o que não convém a ela, às mulheres do mundo) pela qual consegue convencer o leitor a dizer "ei., não dá para deixar de refletir...", não há como esconder o corpo feminino que aqui reverbera, que permanece nas páginas amareladas dessa revista.

Goellner, a partir do ponto de vista de sua área de estudo, aponta que a Revista Educação Physica apresenta um conjunto de discussões sobre os papéis historicamente atribuídos para os corpos femininos e sobre toda uma ideologia que objetiva educá-los, deixálos mais aptos... limpos... belos... femininos... ma-

Movimento Porto Alegre, v.9, n. 3, p.165-173, set./dez. de 2003 
temais - caracterizações presentes até os nossos dias em suas sempre atualizadas roupagens. A autora vai mostrando como a ordenação social visava a instituir uma nova figura de corpo-mulher. A educação feminina torna-se, nesse contexto, um ponto chave para a Educação Física, pois, por meio dela, pretendia-se o aperfeiçoamento das mães e, conseqüentemente, das futuras gerações do país.

Vê-se, então, por meio da análise da autora, o quanto o corpo feminino estava inscrito em políticas modernizadoras e também como estas forjavam uma outra mentalidade - burguesa - para os corpos femininos: a mulher como reorganizadora das vivências sociais e, especialmente, como guardiã dos cuidados dos corpos e da saúde da família. A autora faz-nos ver que os discursos na revista dirigem-se para a "nova mulher" em tons dúbios, como progressistas e moralistas. Ao mesmo tempo em que alguns discursos seduzem e desafiam as mulheres em direção de novas formas de cuidar do corpo, outros discursos cerceiam os possíveis atrevimentos em relação a esses cuidados.

A Revista Educação Physica exibe diferentes recomendações em relação aos cuidados com os corpos das mulheres. A prática esportiva, o cuidado com a aparência ("beleza se constrói") (p.32), o desnudamento do corpo e o uso de artifícios estéticos são identificados como impulsionadores da modernização da mulher e da sua auto-afirmação na sociedade. Nesse sentido, a autora paulatinamente identifica o lugar da atividade física na revista como um discurso voltado para a produção da "nova mulher" - moderna, ágil, companheira, capaz de enfrentar os desafios dos novos tempos. A Revista Educação Physica associa a "nova mulher" com atributos de coragem, ousadia, liberdade de movimento e de ações, sagacidade e sensualidade.

A atividade física é considerada uma prática importante na urgência de civilizar o país. O processo de civilização começaria, então, pela educação dos corpos, redefinindo hábitos, atitudes e comportamentos. A atividade física passa a ser indicada para os corpos femininos como elemento necessário à construção de um estado satisfatório de saúde, ao mesmo tempo em que representa um exercício de sociabilidade que se afirma em espaços até então considerados ou tidos como domínio masculino: a rua, o clube, os estádios e os ginásios, as praças, os parques. 
Analisando essas tendências que se deixam visualizar na Revista Educação Physica, Silvana Goellner, com sensibilidade, vê nas páginas da publicação três eixos que ecoam quase como um mandamento na "feitura" do corpo feminino: seja bela, seja maternal e seja feminina.

Para a autora, é significativa a correlação que aparece, na Revista Educação Physica, entre a prática da atividade física e a beleza feminina. A revista destaca "truques" para melhor cuidar do corpo ou, melhor dizendo, truques atrelados a promessas de melhora da aparência corporal. Dentre esses, o destaque é a atividade física para embelezamento das mulheres, o que seria acrescido da aquisição e manutenção de um bom estado de saúde.

"Feiúra se trata" (idéia da medicalização da beleza) - a beleza "não é um atributo natural das mulheres, é resultante de um trabalho árduo e constante" (p. 32), fruto de uma conquista que se viabiliza mediante esforço individual, disciplina e dedicação bem como por meio de mudança de hábitos e atitudes, cuidados com a pele e com as roupas, mas principalmente pela prática da atividade física. A beleza é transformada em um empreendimento pessoal. A mulher passa, em grande parte dos artigos da revista, a ser responsabilizada pela aparência, sendo instigada a desenvolver o hábito do exercício físico, apurar seu conhecimento sobre aspectos estéticos e higiênicos, incorporar determinados padrões corporais e administrar seu corpo, mode-lando-o e moldando sua força e energia. Ser bela exige da mulher um corpo em movimento, o abandono dos espartilhos e a prescrição de exercícios (para as diferentes partes do corpo). E é em movimento que, nas páginas da revista, o corpo feminino aparece: nadando, no trampolim, na quadra de tênis.

Para a autora, a Revista Educação Physica, em inúmeros artigos, citações e imagens, exalta a maternidade "como a mais encantadora e sublime missão da mulher", afirmando que "é da mãe a responsabilidade não só de gerar, mas também de criar filhos fortes e sadios, futuro promissor de um país que se moderniza" (p. 59).

Os editores publicam textos embevecidos pelas idéias da importância da prática de atividades físicas na preparação da saúde pessoal e social da população. A Educação Física é vista como uma prática social destinada a dar aos homens e às mulheres o máximo de eficiência física para a vida. A mulher, por 
sua relação com a maternidade, precisaria ser identificada com a prática racional de exercícios físicos, conforme algumas passagens das revistas que destaco aqui: "a mulher tem uma responsabilidade muito maior no destino da espécie, no melhoramento da raça, na organização de um futuro melhor para o homem (...) é necessário que ela esteja em condições de transmitir aos filhos todas as qualidades que devem constituir esse individuo normal, senão perfeito" (p.65). A maternidade exigiria, deste modo, a preparação física de um corpo fortalecido e o refinamento das emoções, valorizando-se qualidades como a generosidade, o recato e a abnegação (virtudes oriundas de uma moral burguesa).

Segundo a autora, a revista elabora duas representações de mãe que se revezam ao longo das edições: a mulher-mãe e a mãe-cívica. A representação da mulher-mãe estaria mais voltada para o fortalecimento da raça no que diz respeito à saúde, ao vigor físico e à eficiência dos indivíduos frente aos obstáculos da vida moderna. A mulher-mãe reconhece a importância das atividades corporais e esportivas para o aperfeiçoamento da reprodução humana. Já a mãecívica incorpora e defende o discurso oficial da preservação da soberania nacional e da honra nacional, acentuando a importância da prática de atividades físicas na preparação da mulher-mãe e na regeneração da raça brasileira.

Para Silvana Goellner, a importância do exercício físico para a mulher-mãe no discurso da Revista Educação Physica, desde 1930, afirmou-se pela necessidade da construção de um corpo educado, que preservasse a saúde, cujos benefícios são tanto individuais quanto coletivos, porque do corpo da mãe depende o vigor do filho e, por conseqüência, o vigor (ou não) das futuras gerações.

Preparar, garantir, conduzir a maternidade com êxito traduz vontades pessoais e políticas que reclamam preocupações e orientações específicas, voltadas para a vigilância do corpo feminino. Nesse contexto, é preconizado que a mulher-mãe cultive normas e condutas, evitando esbanjamentos e violências, sendo indispensável que ela aprenda "determinadas formas de ser, de se comportar, de se expressar e de se movimentar com a intenção de salvaguardar aquele que é seu maior atributo: carregar no próprio corpo a esperança de uma outra vida" (p.95). Desta forma, seria possível dizer que o corpo da mulher-grávida inspira mais respeito que desejo, é menos profano que sagrado, reclama reverências porque portador da vida. $O$ corpo da mãe é esculpido no detalhe do seu sexo, 
abrandado nas suas conotações eróticas. É ventre, pulsão e promessa. É sexo em ação e é controle do sexo. É afirmação e negação da sua sexualidade. É uma construção cultural e um olhar especifico sobre o corpo feminino que, ao mesmo tempo, o limita e engrandece (p. 97).

Goellner destaca, ainda, que a revista aponta as vantagens da atividade física também para a mulher que estuda, que trabalha, tanto na idade madura quanto na velhice. Os exercícios físicos seriam, então, um componente importante na construção do corpo e dos comportamentos, objetivo que, para além de ser individual, seria também coletivo

Silvana Goellner também mostra-nos que a Revista Educação Physica produz e reproduz, além das representações de beleza e de maternidade, ainda uma outra: a de feminilidade... Mulher tem que ser feminina? O que é feminizar a mulher? A Educação Física poderá contribuir para a feminização da mulher?

Feminizar a mulher é feminizar a aparência do corpo: a postura, a voz, o rosto, os gestos, os modos de vestir, a externalização de sua sexualidade. É tratar o corpo feminino como algo a ser manipulado, vigiado e modificado por diferentes intervenções. Dentre elas, as práticas corporais e esportivas são identificadas como possibilidade de experiências que libertam, feminizam e sensualizam os gestos, como diz a autora, "trazendo-os à flor da pele". Essas práticas são dosadas de modo a tornar o corpo feminino "nem demais" (anormal) "nem de menos" feminizado.

É interessante como a autora faz o/a leitor/a perceber sutilezas do discurso da publicação que, quando menciona as indicações das práticas corporais e esportivas dirigidas às mulheres, sugere um abrandamento de seus efeitos, tais como: suor excessivo, esforço demasiado, emoções fortes, competições, rivalidade, perigos de lesões, seminudez. Outro destaque: a autora mostra o quanto a Revista Educação Physica, ao mesmo tempo em que incentiva a exercitação e critica a indolência, circunscreve o grau de envolvimento que a mulher deve ter para com os esportes ou a quantidade de esforço a que pode submeter seu corpo.

Quem abre esse livro sente-se tentado/a a prosseguir a leitura, pois trata-se de um texto fluído, escrito de forma leve, o que é louvável e pouco comum na linguagem acadêmica. Identifica-se na obra um estilo que saltita, que se irradia, que apresenta leveza e soltura e produz um efeito de aproximações e de

Movimento Porto Alegre, v.9, n. 3, p.165-173, set./dez. de 2003 
distanciamentos. Enfim, é uma escrita que não tem a pretensão de "acertar na mosca". O livro de Silvana Goellner emerge como leitura indispensável não somente para os profissionais da Educação Física, mas também para os da Medicina, da Pedagogia, da História, da Fisioterapia e, ainda, para grupos de estudos feministas, visto que é um convite à reflexão.

\begin{abstract}
"Bella, maternal y femenina. Imágenes de la mujer en la Revista Educação Physica, por Silvana Goellner, ljuí: Unijuí, 2003 Coleción Educación Física) Resumen: el libro «Bella, maternal y femenina.

Imágenes de la mujer en la Revista Educação Physica» es fruto de la tesis de doctorado defendida por Silvana Goellner junto al Programa de Educación -UNICAMP-Campinas. Goellner, de forma inteligente y original, explora en la exactitud la Revista Physica que circulo en Brasil entre los años de 1932 y 1945. La autora destaca, inicialmente, el tiempo en que la Revista Educação Physica fue producida. En seguida, pregunta: Cuál es el lugar de la Educación Física en ese tiempo? De este modo, su análisis es fuertemente situado y centrado en la historia y en el cuerpo femenino. Silvana Goellner, con sensibilidad, ve en las páginas de la publicación tres ejes que repercuten casi como un j mandamiento en el «hacer» del cuerpo femenino: sea bella, sea maternal y sea femenina. Palabras-clave: Cuerpo, Género, Educación Física.
\end{abstract}

Movimento Porto Alegre, v.9, n. 3, p.165-173, set./dez. de 2003 
Beautiful, maternal and feminine. Images of women in the Physical Education Review, by Silvana Goellner, ljuí: Unijuí, 2003 (Physical Education collection)

Abstract: The book Beautiful, maternal and feminine. Images of women in the Physical Education Magazine is fruit of the doctoral thesis by Silvana Goellner as part of the Educational Programme-UNICAMP-Campinas. Goellner, in an intelligent and original way, exhaustively explores the Physical Education Magazine which was issued in Brazil between 1932 and 1945. Initially, the author focuses on the period of time when the Physical Education Magazine was produced. Later, she raises the question: what is the place of Physical Education in that period of time? This way, her analysis is strongly centred on history and on the feminine body. Silvana Goellner sensitively sees on the pages of the publication three aixis that echo almost like a command of the "making" of the feminine body: be beautiful, be maternal and be feminine. Keywords: Body, Gender, Physical Education.

Recebido em: 28/09/2003

Maria Simone Vione Schwengber

José Bonifácio 1521

ljuí-Rs

98700-000

simone@admijui.unijui.tche.br

Movimento Porto Alegre, v.9, n. 3, p.165-173, set./dez. de 2003 